\title{
Relationship between cortisol response to stress and behavior, immune profile, and production performance of dairy ewes
}

\author{
M. Caroprese, ${ }^{*} \dagger^{1}$ M. Albenzio, ${ }^{*} \dagger$ A. Marzano, ${ }^{*}$ L. Schena, $\dagger$ G. Annicchiarico, $\ddagger$ and A. Sevi ${ }^{*} \dagger$ \\ *Dipartimento PRIME, and \\ †Istituto per la Ricerca e le Applicazioni Biotecnologiche per la Sicurezza e la Valorizzazione dei Prodotti Tipici e di Qualità (BIOAGROMED), \\ Università di Foggia, Via Napoli 25, 71100 Foggia, Italy \\ ¥CRA-Istituto Sperimentale per la Zootecnia, 71122 Segezia-Foggia, Italy
}

\section{ABSTRACT}

The existence of a relationship between cortisol levels, after an acute stress, and behavioral activities, immunological profile, and production performance in sheep was studied. An initial flock of 30 Comisana ewes was involved in the experiment, and each of the 30 ewes was individually subjected to an isolation test in a novel environment. Subsequently, from the initial flock, 2 groups of 8 Comisana ewes were each retrospectively selected, and the animals were divided, according to their cortisol concentration $10 \mathrm{~min}$ after the isolation test, into high cortisol (HC) ewes, having a peak of cortisol concentration $>90 \mathrm{ng} / \mathrm{mL}$ (average: $119.3 \mathrm{ng} /$ $\mathrm{mL} \pm 11.8$ ), and low cortisol (LC) ewes having a peak of cortisol concentration $<80 \mathrm{ng} / \mathrm{mL}$ (average: $52.4 \pm$ 11.8). During the isolation test, the behavior of each animal was video-recorded and behavioral activities were registered. Blood samples were collected before the isolation test, immediately after the test (10 min), and at $60,120,300 \mathrm{~min}, 24 \mathrm{~h}$, and $48 \mathrm{~h}$ after the test to evaluate percentages of T-helper $\left(\mathrm{CD} 4^{+}\right)$and $\mathrm{T}$ cytotoxic $\left(\mathrm{CD} 8^{+}\right)$cells, $\mathrm{CD} 4^{+} / \mathrm{CD} 8^{+}$ratio, and IL-1 $\beta$ and IL- 6 levels. The ewes were milked for $3 \mathrm{~d}$ after the isolation test to determine cortisol levels and IL-1 $\beta$ and IL-6 concentrations in whey. Milk yield was recorded at each milking, and milk samples were analyzed for $\mathrm{pH}$, nutritional parameters, renneting properties, and somatic cell count. During the isolation test, HC ewes exhibited a shorter duration of movement and fewer bleats than LC ewes. The average plasma IL-1 $\beta$ concentration was higher in $\mathrm{HC}$ than in $\mathrm{LC}$ ewes. The average whey IL-1 $\beta$ and IL-6 concentrations were higher in whey from $\mathrm{HC}$ ewes than in $\mathrm{LC}$ ewes. A positive correlation emerged between plasma and whey IL-1 $\beta$ concentrations. The average $\mathrm{CD} 4^{+} / \mathrm{CD} 8^{+}$ratio in blood was lower in $\mathrm{HC}$ than in $\mathrm{LC}$ ewes. Time from isolation affected the $\mathrm{CD}^{+} / \mathrm{CD}^{+}$ratio: at $120 \mathrm{~min}$, the $\mathrm{CD} 4^{+} /$

Received July 30, 2009.

Accepted February 23, 2010.

${ }^{1}$ Corresponding author: m.caroprese@unifg.it
$\mathrm{CD} 8^{+}$ratio increased compared with that at $10 \mathrm{~min}$ after isolation and then decreased until $300 \mathrm{~min}$ after isolation. On average, ewes with low cortisol concentrations showed higher milk production and lower SCC than ewes with high cortisol concentrations. Results suggest that plasma cortisol concentration is connected to the behavioral response and immune competence of dairy ewes and cytokine concentrations. Both whey IL-1 $\beta$ and IL- 6 can be considered reliable indicators of the magnitude of hypothalamic-pituitary-adrenal axis activation. The stress-induced changes in $\mathrm{CD}^{+} /$ $\mathrm{CD} 8^{+}$ratio are critical for controlling disease incidence and planning appropriate vaccination programs. High reactivity of the hypothalamic-pituitary-adrenal axis is also associated with a reduction in milk production and an increased predisposition to develop intramammary inflammatory processes.

Key words: welfare, dairy ewe, cortisol, cytokine

\section{INTRODUCTION}

Domestic animals react to stress by an alteration of behavioral and physiological responses, which are the results of individual emotional reactivity (Deiss et al., 2009). The first response to stress is the behavioral one, which can be considered the cheapest response in terms of the biological cost for the animal (Moberg, 2000). The physiological response to stress includes activation of the central nervous system and the endocrine and immune systems, and it can affect the animal's production performance. In sheep, different studies demonstrated the worsening of production performance in response to stressful management procedures (Sevi et al., 2001a,b; Caroprese et al., 2009). The central nervous and immune systems are connected through the activation of the autonomic nervous system and the hypothalamic-pituitary-adrenal (HPA) axis by the secretion of numerous molecules such as neuropeptides and neurohormones, which are responsible for changes in cellular and humoral immune responses (Borghetti et al., 2009). In animals and humans, an increase of proinflammatory cytokines, which can give a very early 
prediction of ongoing stress, has been observed after acute psychological stress (Black, 2002). Stress-induced hypercortisolemia can affect the number of circulating lymphocytes (Griffin, 1989; Dhabhar et al., 1996, 2009). Fluctuations in the number and percentage of peripheral blood lymphocytes and T-lymphocyte subsets have an effect on animal immunocompetence. The T-helper $\left(\mathbf{C D} 4^{+}\right)$cells can activate both humoral and cellmediated immunity (Day, 2000), whereas T-cytotoxic $\left(\mathbf{C D 8}^{+}\right)$cells are involved in the immune surveillance of peripheral tissues and in the elimination of pathogens (Park et al., 1992; Mehrzad et al., 2008). Shifts in T-cell subsets can affect the activity of other immune cells and their secretions, thus affecting susceptibility to clinical or subclinical diseases (Mehrzad et al., 2008). Consequently, an animal's response to stress, in terms of cytokine secretion and lymphocyte distribution, may affect its predisposition to disease or stress-related pathologies.

In human and animal studies, the existence of individuals within a population of conspecifics with different stress-reaction patterns has been demonstrated (Koolhaas et al., 1999; Kunz-Ebrecht et al., 2003). Cows with a strong adrenocortical response to isolation showed a larger reduction in the number of peripheral blood lymphocyte than cows with a weak adrenocortical response during endotoxin-induced mastitis (Hopster et al., 1998). As a result, individual differences in stress reactivity may play a role in the animal's ability to face aversive situations and to cope with immunological challenges.

Assessment of animal well-being requires procedures that can be stressful for animals. Several studies have been conducted to determine welfare indicators in biological fluids other than blood, such as milk cortisol (Verkerk et al., 1998), salivary cortisol (Fell et al., 1985; Negrão et al., 2004), milk-antigen-specific IgG concentrations (Caroprese et al.2006a,b), and milk amyloid A (Winter et al., 2006). To our knowledge, no studies have monitored immunological and endocrine parameters in milk under routine milking.

The aim of this study was to investigate the relationship between differing degrees of adrenocortical response to stressful procedures and behavioral responses, immune functions, and the production performance of dairy ewes.

\section{MATERIALS AND METHODS}

\section{Experimental Design}

The experiment was performed at Segezia Experimental Station of the Italian Consiglio per la Ricerca e la Sperimentazione in Agricoltura at the end of Janu- ary, and initially involved 30 lactating Comisana ewes. The ewes, aged from 4 to $6 \mathrm{yr}$ and at $90 \pm 1.10 \mathrm{DIM}$, were housed on straw litter in three $8 \mathrm{~m} \times 3 \mathrm{~m}$ pens. Each pen was provided with 2 mangers and a crib. The ewes were offered $1 \mathrm{~kg}$ of a pelleted concentrate and 1.8 $\mathrm{kg}$ of vetch/oat hay daily, provided in 2 meals a day (0730 and $1500 \mathrm{~h}$ ). Water was available ad libitum. The ewes were healthy and their health was carefully monitored by veterinarians to exclude the presence of signs of clinical mastitis (pain, gland swelling, and fever). A small quantity of milk was checked visually for signs of mastitis (flakes, clots, or blood). No cases of mastitis were detected during the study period.

At the beginning of the experiment (d 0), the ewes were subjected to an isolation test for $10 \mathrm{~min}$, performed soon after the morning milking, starting at 1000 h. During the isolation test, each ewe was exposed to a novel environment ( $4 \mathrm{~m} \times 4 \mathrm{~m}$ pen) and isolated from tactile and visual contact with conspecifics for $10 \mathrm{~min}$, although the isolated ewe was subjected to auditory and olfactory stimuli from the other animals. The behavior of each animal was video-recorded (DVD-DCR 403E, Sony, Tokyo, Japan), and behavioral activities were registered for the 10-min period. In each observation period, the latency time of movement, the duration of movement, and the duration of the exploratory activities were observed for the 10-min period and measured in seconds. In addition, the number of bleats and attempts to climb over the pen fence and the number of defecations and urinations were recorded for the 10-min period.

\section{Blood Collection and Cortisol Analyses}

Blood samples $(10 \mathrm{~mL})$ were collected in heparinized vacuum tubes from the jugular vein immediately before the isolation test, soon after the test (10 min), at 60,120 , and $300 \mathrm{~min}$, and then $24 \mathrm{~h}$ and $48 \mathrm{~h}$ after the test to determine plasma cortisol concentrations. Hormone concentration was determined by a competitive enzyme immunoassay kit for cortisol determination (Radim, Pomezia, Italy). Validation for ovine plasma was performed as described by Fisher et al. (1997). The sensitivity of the assay was $5 \mathrm{ng} / \mathrm{mL}$; the inter- and intraassay coefficients of variation were 6.2 and $6.9 \%$, respectively.

\section{Classification of Animals According to Thresholds Set for Plasma Cortisol}

The animals were retrospectively grouped according to their plasma cortisol concentrations. In particular, 16 subjects were selected from the flock of 30 Comisana ewes, divided into 2 groups of 8 ewes each character- 


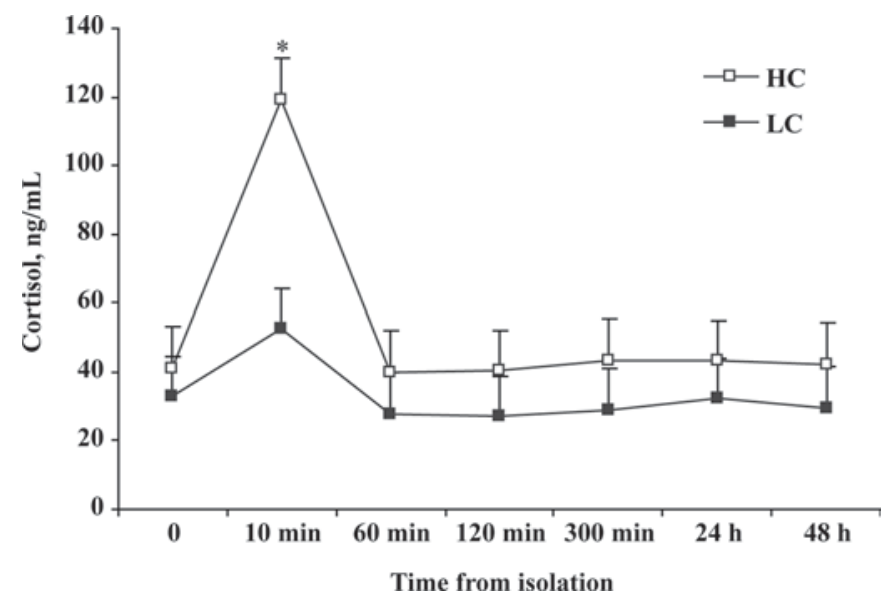

Figure 1. Plasma cortisol concentrations (LSM \pm SEM) measured at 10,60, 120, and $300 \mathrm{~min}$ and then $24 \mathrm{~h}$ and $48 \mathrm{~h}$ after the isolation test in ewes with high ( $\mathrm{HC})$ and low (LC) cortisol concentrations. Differences between the groups at each time point are represented by an asterisk $(* P<0.05)$.

ized by a low or high concentration of cortisol. Animals with a cortisol concentration $>90 \mathrm{ng} / \mathrm{mL}$ (measured 10 min after isolation) were identified as high cortisol concentration ewes (HC group; average of peak cortisol concentration: $119.3 \mathrm{ng} / \mathrm{mL} \pm 11.8$ ), whereas animals having a cortisol concentration $<80 \mathrm{ng} / \mathrm{mL}$ were identified as low cortisol concentration ewes (LC group; average of peak cortisol concentration: $52.4 \mathrm{ng} / \mathrm{mL} \pm$ 11.8; Figure 1). The baseline levels of cortisol concentration measured before exposure to isolation were not different between the groups. Animals with a peak of cortisol concentration ranging from 80 to $90 \mathrm{ng} / \mathrm{mL}$ were excluded from the experiment.

\section{Differential Count of Leukocyte Populations}

For each blood sample collected before the isolation test, the percentage of lymphocyte T-helper $\left(\mathrm{CD} 4^{+}\right)$ cells, lymphocyte T-cytotoxic $\left(\mathrm{CD} 8^{+}\right)$cells, and total lymphocytes were determined immediately after the test (10 min), and at 60,120, $300 \mathrm{~min}, 24 \mathrm{~h}$, and $48 \mathrm{~h}$ after the test, by using a flow cytometer (Coulter Epics XL-MCL, Beckman Coulter, Fullerton, CA) according to Lloyd et al. (1995) with some modifications. Flow cytometry analysis allows the identification of cells by labeling with appropriate antibodies conjugated to fluorochromes. Blood samples $(100 \mu \mathrm{L})$ were incubated for $30 \mathrm{~min}$ with $0.02 \mathrm{mg} / \mathrm{mL}$ of mouse anti-ovine CD4 monoclonal antibody conjugated to fluorescein isothiocyanate (MCA2213F, Serotec, Oxford, UK), diluted in PBS ( $\mathrm{pH} 7.4)$ and sodium azide $\left(\mathrm{NaN}_{3}, 0.02 \%\right)$ for detecting $\mathrm{CD}^{+}$cells, and with $0.02 \mathrm{mg} / \mathrm{mL}$ of mouse anti-ovine CD8 monoclonal antibody conjugated to phycoerythrin (MCA2216PE, Serotec), diluted in PBS and $\mathrm{NaN}_{3}(0.02 \%)$ for detecting $\mathrm{CD}^{+}$cells. Subsequently, red blood cells were lysed using Q-Prep Epics Immunology Workstation (Beckman Coulter). The samples were acquired by flow cytometry (Cell Lab Quanta SC, Beckman Coulter). Linear amplification of the forward scatter and side scatter light signals were set with logarithmic amplification of the fluorescence signals. The $488 \mathrm{~nm}$ excitation wavelength was used. For each sample, 10,000 total events were collected. Lymphocytes were selected for analysis by gating on the forward scatter and side scatter dot plot. Fluorescence of fluorescein isothiocyanate and phycoerythrin was measured through 530/30 and 585/42 band pass filters, respectively; fluorescein isothiocyanate (FL1) versus phycoerythrin fluorescence (FL2) was then used to determine the ratio of $\mathrm{CD} 4^{+} / \mathrm{CD} 8^{+}$.

\section{Milk Collection and Laboratory Analyses}

The day before the isolation test, the ewes were milked in the afternoon at $1500 \mathrm{~h}(-19 \mathrm{~h}$ from isolation). Then, on the day of the isolation test, the ewes were milked $2 \mathrm{~h}$ before the isolation test, and then at 5 , 22, 29, 46, and $53 \mathrm{~h}$ from isolation. Ewes were milked twice daily (0800 and $1500 \mathrm{~h}$ ) using pipeline milking machines (Alfa Laval Agri, Tumba, Sweden). At each milking, individual milk production was measured by means of graduated measuring cylinders attached to individual milking units, and milk samples were collected and transported to the laboratory by means of transport tankers at $4^{\circ} \mathrm{C}$. The following analyses were carried out: fat, total protein, and lactose contents using an infrared spectrophotometer (MilkoScan 133B, Foss Electric, Hillerød, Denmark) according to the IDF (1990) standard. Somatic cell count was evaluated using a Foss Electric Fossomatic 90 cell counter (IDF, 1995). Renneting characteristics (clotting time, rate of clot formation, and clot firmness after $30 \mathrm{~min}$ ) were measured using a Foss Electric Formagraph. At each sampling time, a milk aliquot from each ewe was centrifuged at $2,000 \times g$ for $30 \mathrm{~min}$ at $4^{\circ} \mathrm{C}$ to separate whey from fat and somatic cells. Whey cortisol levels were determined using the same procedure as used on plasma samples.

\section{Determination of Blood and Whey Interleukins}

For each blood and milk sample collected, concentrations of IL- 6 and IL- $1 \beta$ were measured. The detection of IL- 6 and IL-1 $\beta$ in plasma and in whey was determined by capture ELISA performed on 96-well microtiter plates according to Caroprese et al. (2006a). Mouse monoclonal antibodies specific for ovine IL-6 and for ovine IL-1 $\beta$ (Serotec Ltd.; $100 \mu \mathrm{L}, 5 \mu \mathrm{g} / \mathrm{mL}$ ) 
Table 1. Least squares means and SEM of behavioral traits measured during isolation test of ewes with high (HC) and low (LC) cortisol concentrations

\begin{tabular}{lcccc}
\hline Item & LC & HC & SEM & $\begin{array}{c}P \text {-value } \\
\text { (cortisol level) }\end{array}$ \\
\hline Latency time to movement, s & 4.06 & 4.68 & 0.44 & NS \\
Duration of movement, s & 101.69 & 77.06 & 3.84 & $* * *$ \\
Duration of time spent in investigation, s & 38.18 & 28.5 & 5.88 & NS \\
Bleats, n & 55.37 & 40.50 & 3.72 & $* *$ \\
Climbing attempts, n & 5.75 & 0.25 & 2.7 & NS \\
Defecations, n & 0.25 & 0.12 & 0.197 & NS \\
Urinations, n & 0.62 & 0.37 & 0.226 & NS \\
\hline
\end{tabular}

NS: $P>0.05 ; * * P<0.01 ; * * * P<0.001$

dissolved in $50 \mathrm{~m} M$ carbonate buffer ( $\mathrm{pH} 9.6$ ) were used to coat wells; plates were incubated overnight at $4^{\circ} \mathrm{C}$. After washing with PBS (pH 7.2) and $0.05 \%$ Tween 20 (PBST), the plates were incubated with $200 \mu \mathrm{L}$ of $10 \%$ reconstituted commercial bovine skim milk at $37^{\circ} \mathrm{C}$ for $1 \mathrm{~h}$ to block nonspecific binding. Plates were then washed 4 times with PBST, plasma or whey $(50 \mu \mathrm{l}$ per well) was added, and the plates incubated at $37^{\circ} \mathrm{C}$ for $1 \mathrm{~h}$. Negative control wells contained only PBST. Following overnight incubation, the plates were washed 4 times with PBST. Rabbit polyclonal antibody antiovine IL-6 and anti-ovine IL-1 $\beta$ (Serotec Ltd.) were used as detecting antibodies $(0.005 \mathrm{mg} / \mathrm{mL}$ diluted in $3 \%$ BSA in PBST) to determine captured IL-6 and IL$1 \beta$; plates were incubated at $37^{\circ} \mathrm{C}$ for $1 \mathrm{~h}$. The presence of binding for IL-6 and IL-1 $\beta$ was detected using sheep anti-rabbit IgG conjugated to horseradish peroxidase (Sigma Aldrich, Milan, Italy). Optical density was measured at $450 \mathrm{~nm}$. Plasma and whey samples were read against a standard curve obtained using scalar dilutions of recombinant ovine IL-1 $\beta$ and IL-6 from Garry Barcham of the Centre for Animal Biotechnology (School of Veterinary Sciences, The University of Melbourne, Australia). Data for concentrations of IL- $1 \beta$ and IL-6 were expressed as nanograms of per milliliter. The inter- and intraassay coefficients of variation were 6.09 and $3.29 \%$ and 6.12 and $9.13 \%$ for IL- $1 \beta$ and IL-6 in plasma, respectively. The inter- and intraassay coefficients of variation were 3.65 and $7.15 \%$ and 9.37 and $5.98 \%$ for IL-1 $\beta$ and IL- 6 in whey, respectively.

\section{Statistical Analysis}

All variables were tested for normality using the Shapiro-Wilk test (Shapiro and Wilk, 1965) and, when necessary, transformed into logarithm form to normalize their frequency distribution. Then, data were processed by ANOVA, using the GLM procedure for repeated measures (SAS Institute, 1999).

The model utilized was

$$
\mathrm{y}_{\mathrm{ijkl}}=\mu+\alpha_{\mathrm{i}}+\beta_{\mathrm{ij}}+\gamma_{\mathrm{k}}+(\alpha \gamma)_{\mathrm{ik}}+\varepsilon_{\mathrm{ijkl}},
$$

where $\mathrm{y}_{\mathrm{ijkl}}=$ dependent variable, $\mu=$ the overall mean; $\alpha=$ cortisol threshold; $\beta=$ animal effect within cortisol concentration; $\gamma=$ time from isolation; $\alpha \gamma=$ interaction of cortisol threshold $\times$ time from isolation, and $\varepsilon=$ error. For blood $\mathrm{CD} 4^{+} / \mathrm{CD} 8^{+}$ratio, the values measured at the beginning of the experiment were used as covariates. When significant effects were found $(P$ $<0.05)$, Student's $t$-test was used to locate significant differences between means. Linear simple correlations between whey and blood variables were investigated using PROC CORR (SAS Institute, 1999).

\section{RESULTS}

\section{Behavioral Parameters}

During the isolation test, the ewes displaying low cortisol concentration after isolation exhibited a longer duration of movement and a higher number of bleats than the ewes with high cortisol concentration $(P<$ 0.001 and $P<0.01$, respectively; Table 1$)$. No differences were found in the latency time to movement, the time spent in investigation, the number of attempts to climb out of the pen, or the number of urinations and defecations.

\section{Blood and Whey Immunological Determinations}

Results obtained from plasma cytokine assays showed that LC ewes had lower mean IL-1 $\beta$ concentration than HC ewes $(P<0.01$; Table 2$)$. The plasma IL- 6 concentration was $16 \%$ higher in $\mathrm{HC}$ ewes than in LC ewes, even though no significant differences emerged between the groups.

The average concentrations of IL- $1 \beta$ and IL- 6 were significantly lower in the whey of the ewes in the LC group than in that of ewes in the HC group $(P<0.01$ and $P<0.05$, respectively). Positive correlations $(\mathrm{r}=$ $0.277 ; P<0.05)$ emerged between plasma and whey IL$1 \beta$ concentrations. No significant correlation was found between plasma and whey IL-6. 
Table 2. Least squares means and SEM of plasma and whey IL-1 $\beta$ and plasma and whey IL-6 concentrations measured in ewes with high (HC) and low (LC) cortisol secretion after isolation

\begin{tabular}{lrrrccc}
\hline & & & \multicolumn{3}{c}{$P$-value } \\
\cline { 5 - 7 } Item & \multicolumn{1}{c}{$\mathrm{LC}$} & $\mathrm{HC}$ & $\mathrm{SEM}$ & Cortisol level $(\mathrm{C})$ & Time $(\mathrm{T})$ & $\mathrm{C} \times \mathrm{T}$ \\
\hline Plasma IL-6, $\log _{10} \mathrm{ng} / \mathrm{mL}$ & 0.20 & 0.24 & 0.02 & NS & NS & NS \\
Plasma IL1 $\beta, \mathrm{ng} / \mathrm{mL}$ & 10.17 & 13.81 & 1.14 & $* *$ & $\mathrm{NS}$ & $\mathrm{NS}$ \\
Whey IL-6, $\log _{10} \mathrm{ng} / \mathrm{mL}$ & 0.11 & 0.18 & 0.02 & $*$ & NS & NS \\
Whey IL-1 $\beta, \mathrm{ng} / \mathrm{mL}$ & 2.79 & 5.07 & 0.68 & $* *$ & NS & NS \\
\hline
\end{tabular}

NS: $P>0.05 ;{ }^{*} P<0.05 ;{ }^{* *} P<0.01$.

After isolation, no significant differences between LC and $\mathrm{HC}$ ewes for $\mathrm{CD} 4^{+}$cells, $\mathrm{CD} 8^{+}$cells, or lymphocyte percentages of blood were found (Table 3 ). The average $\mathrm{CD} 4^{+} / \mathrm{CD} 8^{+}$ratio in blood was higher in $\mathrm{LC}$ ewes than in $\mathrm{HC}$ ewes $(2.13$ vs. $1.87 \pm 0.07 ; P<0.01)$. Time from isolation affected the $\mathrm{CD} 4^{+} / \mathrm{CD} 8^{+}$ratio: at $120 \mathrm{~min}$ the $\mathrm{CD} 4^{+} / \mathrm{CD} 8^{+}$ratio increased in both groups compared with that at $10 \mathrm{~min}$ after isolation $(2.33 \pm 0.13$ vs. 1.86 $\pm 0.13)$ and then decreased from 120 to 300 min after isolation $(P<0.05$; Figure 2$)$.

\section{Milk Chemical Analysis and Whey Cortisol Concentration}

On average, ewes with a low cortisol concentration showed higher milk production than ewes with a high cortisol concentration $(P<0.05$; Table 4$)$. An interaction of time from sampling $\times$ level of cortisol concentration was observed for milk yield, with LC ewes displaying higher milk yield than $\mathrm{HC}$ ewes $(P<0.05)$ at $46 \mathrm{~h}$ from isolation $(309.37 \pm 38.89$ vs. $443.75 \pm$ $38.89 \mathrm{~g} /$ milking; Figure 3$)$. The mean SCC was higher in milk from $\mathrm{HC}$ than from LC ewes $(P<0.05)$. No significant differences between groups emerged for milk constituents, $\mathrm{pH}$, or renneting parameters. Time from isolation affected milk production, percentages of fat, protein, and lactose, SCC $(P<0.001)$, clot firmness, and rate of clot formation $(P<0.05)$. Differences were ascribed to different volumes of milk from evening and morning milkings of ewes.
No differences for whey cortisol concentration were found between ewes with low and high cortisol concentration (Table 4).

\section{DISCUSSION}

Physiological responses of animals to stress are often correlated with their behavioral responses (Rushen, 2000). The set of physiological and behavioral responses to stress defines a passive response to aversive conditions, characterized by high HPA axis reactivity and low sympathetic reactivity (e.g., low heart rate and cathecolamine secretion). On the contrary, an active response is characterized by low HPA axis reactivity and high sympathetic reactivity (Koolhaas et al., 1999). The short duration of movement and low number of bleats recorded in dairy ewes characterized by a high cortisol concentration after the isolation test indicate a passive coping style, which highlights a relationship between high HPA axis reactivity and withdrawal behavior. The behavioral parameters registered in the LC ewes can typically be considered an active behavioral pattern, confirming the aforementioned hypothesis. Some researchers (Napolitano et al., 2003; Sevi et al., 2003) found that stressful management practices resulted in a withdrawal behavior in sheep isolated in a novel environment.

Both physiological and psychological stressors can determine the secretion of proinflammatory cytokines IL-1 $\beta$, IL-6, and tumor necrosis factor- $\alpha$; in turn, cy-

Table 3. Least squares means and SEM of lymphocytes, T-helper (CD4+) and T-cytotoxic (CD8+) cells, and of $\mathrm{CD}^{+} / \mathrm{CD}^{+}$ratio from blood of ewes with high (HC) and low (LC) cortisol concentrations after isolation

\begin{tabular}{lrrrrrr}
\hline & & & \multicolumn{3}{c}{$P$-value } \\
\cline { 5 - 7 } Item & LC & HC & SEM & Cortisol level $(\mathrm{C})$ & Time $(\mathrm{T})$ & $\mathrm{C} \times \mathrm{T}$ \\
\hline Lymphocytes, $\%$ & 52.22 & 52.95 & 2.56 & NS & NS & NS \\
CD4 $4^{+}$cells, $\%$ & 31.48 & 30.76 & 1.60 & NS & NS & NS \\
CD $^{+}$cells, $\%$ & 17.17 & 17.44 & 1.94 & NS & NS & NS \\
CD $^{+} /$CD $^{+}$ratio & 2.13 & 1.87 & 0.07 & $* *$ & $*$ & NS \\
\hline
\end{tabular}

NS: $P>0.05 ;{ }^{*} P<0.05 ;{ }^{* *} P<0.01$ 


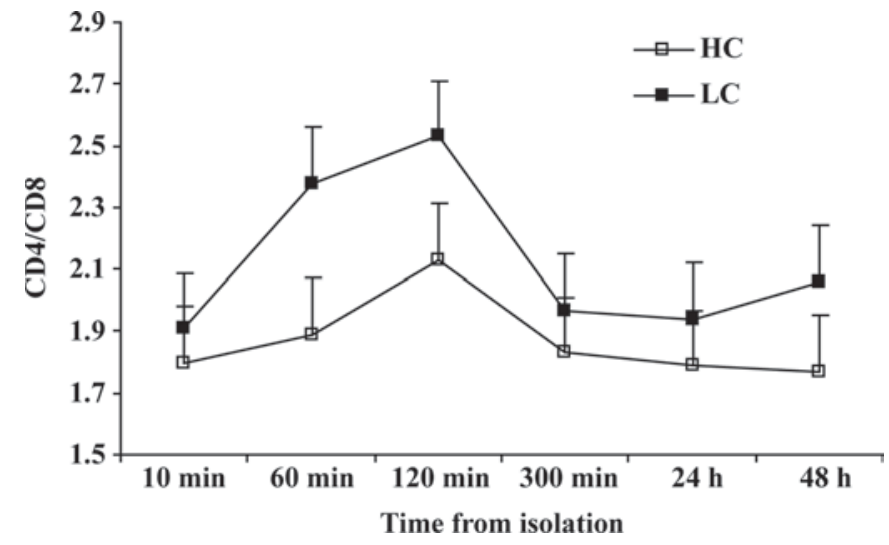

Figure 2. Blood $\mathrm{CD}^{+} / \mathrm{CD} 8^{+}$ratio $(\mathrm{LSM} \pm \mathrm{SEM})$ measured in ewes at 10,60,120, and $300 \mathrm{~min}$ and then $24 \mathrm{~h}$ and $48 \mathrm{~h}$ after the isolation test in ewes with high (HC) and low (LC) cortisol concentrations. $\mathrm{CD}^{+}=$T-helper cells; CD $8^{+}=\mathrm{T}$-cytotoxic cells

tokine production and actions are controlled by cortisol (Black, 2002; Caroprese et al., 2006a). Results from this study demonstrate that differences in cortisol responsiveness are associated with different patterns of plasma IL-1 $\beta$. In this experiment, HC ewes exhibited higher levels of plasma IL-1 $\beta$ than did LC ewes, supporting the hypothesis that sheep with a hyperactive HPA axis have a high immunological reactivity that could increase inflammatory responses. Interleukin- $1 \beta$ is a very powerful inflammatory cytokine whose expression, synthesis, secretion, and activity are tightly regulated events (Dinarello, 1996). The direct relationship found between plasma cortisol and cytokine concentration is in contrast with previous findings reported in humans subjected to mild psychological stress by Kunz-Ebrecht et al. (2003). Those authors found that the cortisol responder group showed lower levels of proinflammatory cytokines than the cortisol nonresponder group. It has been hypothesized, however, that cortisol could

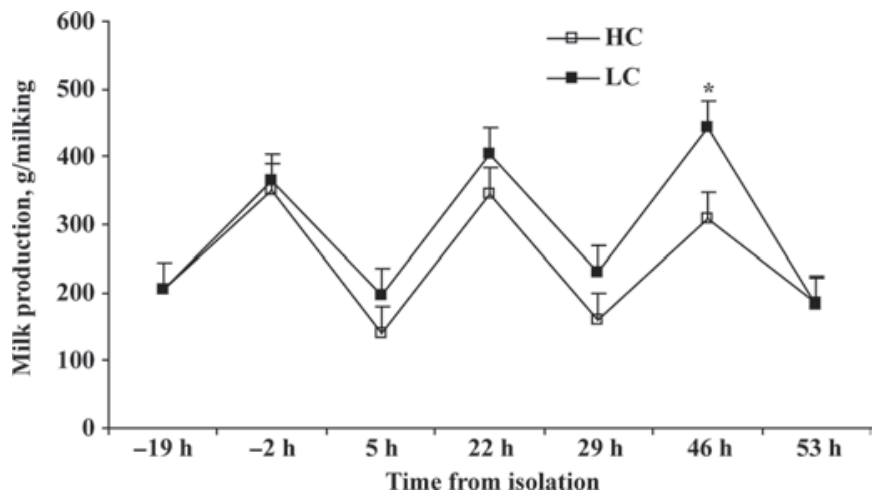

Figure 3. Milk yield (LSM \pm SEM) measured in ewes at $-19,-2$, $5,22,29,46$, and $53 \mathrm{~h}$ relative to the isolation test in ewes with high (HC) and low (LC) cortisol concentrations.

stimulate or inhibit immune responses depending on its concentration. In addition, evidence suggests that chronic stress can reduce the suppressive effects of cortisol on immune functions and induce an enhancement of inflammatory responses (McEwen et al., 1997; McEwen, 1998). In line with the profile of proinflammatory cytokines, it was observed that ewes displaying active reactions during the behavioral test had low levels of cytokines, whereas ewes displaying withdrawal behavior had high levels of cytokines. Evidence exists that proinflammatory cytokines induce "sickness behavior," which is characterized by increased sleeping and decreased activity (Kemeny, 2009).

An appropriate $\mathrm{CD} 4^{+} / \mathrm{CD}^{+}$ratio is important to sustain T-cell homeostasis and immune responses. Although no differences emerged for percentages of $\mathrm{CD}_{4}^{+}$ and $\mathrm{CD} 8^{+}$cells and lymphocytes between groups, a lower $\mathrm{CD}^{+} / \mathrm{CD}^{+}$ratio was measured in $\mathrm{HC}$ ewes compared with LC ewes. Some researchers (Park et al., 1992; Kimura et al., 1999) reported that a $\mathrm{CD} 4^{+} / \mathrm{CD} 8^{+}$ ratio of approximately 2 is indicative of adequate im-

Table 4. Least squares means and SEM of milk production, $\mathrm{pH}$, chemical composition, renneting parameters of milk, and whey cortisol from ewes with high (HC) and low (LC) cortisol concentration after isolation

\begin{tabular}{|c|c|c|c|c|c|c|}
\hline \multirow[b]{2}{*}{ Item } & \multirow[b]{2}{*}{$\mathrm{LC}$} & \multirow[b]{2}{*}{$\mathrm{HC}$} & \multirow[b]{2}{*}{ SEM } & \multicolumn{3}{|c|}{$P$-value } \\
\hline & & & & Cortisol level (C) & Time $(\mathrm{T})$ & $\mathrm{C} \times \mathrm{T}$ \\
\hline Milk production, $\mathrm{g} /$ milking & 289.55 & 243.37 & 13.57 & $*$ & $* * *$ & $*$ \\
\hline $\mathrm{pH}$ & 6.68 & 6.69 & 0.05 & NS & NS & NS \\
\hline Fat, $\%$ & 7.8 & 8.61 & 0.31 & NS & $* * *$ & NS \\
\hline Protein, \% & 5.79 & 5.92 & 0.14 & NS & $* * *$ & NS \\
\hline Lactose, $\%$ & 4.65 & 4.55 & 0.08 & NS & $* * *$ & NS \\
\hline $\mathrm{SCC}, \log _{10}$ cells $/ \mathrm{mL}$ & 5.35 & 5.63 & 0.06 & * & $* * *$ & NS \\
\hline Clot formation time, min & 23.07 & 25.98 & 2.65 & NS & NS & NS \\
\hline Clot firmness, mm & 34.24 & 29.19 & 8.72 & NS & * & NS \\
\hline Rate of clot formation, min & 1.65 & 1.92 & 0.17 & NS & $*$ & NS \\
\hline Whey cortisol, ng/mL & 9.79 & 11.22 & 0.85 & NS & NS & NS \\
\hline
\end{tabular}

NS: $P>0.05 ;{ }^{*} P<0.05 ; * * * P<0.001$. 
munocompetence in the bovine; in $\mathrm{HC}$ ewes, the $\mathrm{CD} 4^{+} /$ $\mathrm{CD} 8^{+}$ratio was always $<2$, suggesting an unbalanced distribution between T-cell subsets and confirming that sheep with hyperactive HPA axis have enhanced immunological functions. Mehrzad et al. (2008) found a decrease in blood $\mathrm{CD} 4^{+} / \mathrm{CD} 8^{+}$ratio in cows subjected to intramammary challenge with Escherichia coli, and an increase in $\mathrm{CD}^{+}$cells trafficking in the site of inflammation. In both groups in the current study, the effect of isolation stress on the $\mathrm{CD} 4^{+} / \mathrm{CD} 8^{+}$ratio appeared evident $2 \mathrm{~h}$ after isolation, when an increase in the $\mathrm{CD}^{+} / \mathrm{CD}^{+}$ratio was measured. Previous studies demonstrated that isolation in sheep could result in an increase of $\mathrm{CD}^{+}$cells and of the $\mathrm{CD} 4^{+} / \mathrm{CD} 8^{+}$ratio (Degabriele and Fell, 2001). Mehrzad and Zhao (2008) found an increased proportion of $\mathrm{CD}^{+}$cells and an increased $\mathrm{CD} 4^{+} / \mathrm{CD} 8^{+}$ratio in pluriparous cows, resulting in an immunological dysregulation compared with primiparous cows. Accordingly, our results showed that immune depression and subsequent increased susceptibility to diseases, which are often observed in animals subjected to stress, could be connected to the imbalance in the proportion of T-cell subsets, resulting in a reduced T-cytotoxic immune response. In addition, our findings can be of practical interest by suggesting that the first $5 \mathrm{~h}$ after stress exposure are crucial for the recovery of immunological competence; the weakness of immune responses in this period has to be considered when possible exposure to pathogens as well as vaccination programs occur.

One of the objectives of the trial was to find a correlation between blood and milk parameters to use milk indicators as detection tools of immunological functions and physiological stress. Concentrations of proinflammatory cytokines in whey, as well as in plasma, were influenced by the level of cortisol concentrations, being higher in $\mathrm{HC}$ than in LC ewes. The lack of correlation between plasma and whey IL-6 is not easy to interpret; a tentative explanation may be found in a circadian release rhythm of IL-6, which has been observed by Maggio et al. (2006) in humans. The secretion pattern of IL-6 together with different times of blood and milk collection could be responsible, at least partly, for different concentrations of IL-6 circulating in the blood and accumulating in the mammary glands of $\mathrm{HC}$ and LC ewes and, consequently, for the failure to find differences in the cytokine concentration in plasma. On the contrary, whey IL-6 levels showed differences between the experimental groups, probably because of the reduced sensitivity to IL-6 fluctuations of the mammary gland compartment with respect to blood. The positive correlation found between IL-1 $\beta$ in plasma and in whey could be connected to the type of stressor tested. In a previous study, detectable concentrations of both IL-1 $\beta$ and IL-6 in sheep whey during the transition period were found, but no correlation between cytokine concentrations in whey and blood emerged (Caroprese et al., 2006a). Thus, we hypothesized that a relationship between blood and milk cytokines exists, depending on the nature and intensity of stress.

Cortisol concentrations in milk and plasma are closely correlated (Shutt and Fell, 1985). The absence of differences observed in whey cortisol concentrations between groups could be ascribed to time of ewe milking after the action of stress. Verkerk et al. (1998) stated that in lactating cows, cortisol measurement in milk can be a useful indicator of acute stressors acting up to $2 \mathrm{~h}$ before sampling. The determination of cortisol in milk fails to give an indication of the effect of stressful situations on sheep if milking does not occur soon after the stressor itself.

In sheep, stressful management procedures can affect both milk production and quality, causing an increase in SCC (Caroprese et al., 2009). In fact, several stressors connected with the activation of HPA and the increased concentration of cortisol have been proven to reduce milk yield (Varner and Johnson, 1983; Hemsworth et al., 2000; Sevi et al., 2001b). Ewes with low cortisol concentrations had, on average, a 19\% higher milk yield than ewes with high cortisol concentrations. There are several possible explanations for the reduction of milk yield in HC ewes: first, the high levels of cortisol could have reduced the blood glucose availability to the mammary gland. Reduced uptake from blood of lactose precursor could have had a role in reducing milk yield, because lactose is the principal osmoregulatory component in milk. Second, reduced milk yield could be the outcome of reduced blood flow to the mammary gland caused by the increase in catecholamines with impairment of the release and action of oxytocin that has been found in stressed animals (Bruckmaier and Blum, 1998). Moreover, immunological stressors and the induction of cytokine secretion may affect nutrient partitioning and divert nutrients away from production toward liver anabolism and the host defense mechanism (Husband, 1995). Together with the association between the extent of cortisol concentration and milk yield, a relationship between cortisol concentration and the levels of SCC was found. The higher SCC observed in milk from the $\mathrm{HC}$ ewes is not easy to explain. Findings about the relationship between the levels of SCC and stress are contradictory, even if the administration of adrenocorticotropic hormones to lactating cows has been proven to increase SCC and decrease milk production (Berning et al., 1987). Evidence exists of a close relationship between poor welfare and increased susceptibility to mastitis (Sevi et al., 2001a). Recent findings suggest that ewes selected for a low SCC had 
higher mastitis resistance than ewes with high SCC and demonstrated a greater ability to limit inflammatory processes of the mammary gland and to prevent the clinical consequences of mastitis (Rupp et al., 2009). Several studies found that behavioral and neuroendocrine responses to stress are genetically mediated and identify distinct phenotypes stable over time (Hopster et al., 1998; Jones and Hocking, 1999). In addition, a close relationship between the behavioral and neuroendocrine responses to stress and immunity has been stated.

\section{CONCLUSIONS}

Results from the present study suggest that the extent of HPA axis activation is responsible for alterations in behavioral and immune responses to stress in sheep. A hyperactive HPA may contribute to enhanced inflammatory responses and the expression of a passive coping style during stressful situations. High HPA reactivity is also associated with a reduction in milk production and an increased predisposition to develop intramammary inflammatory processes. Our findings are consistent with the hypothesis that in dairy ewes a relationship may exist between HPA reactivity and the predisposition of the development of inflammatory processes in the mammary gland. In light of previous considerations, it can be hypothesized that the classification of sheep according to their behavioral and physiological responses to stress could be a useful tool to discriminate those animals with an increased susceptibility to mastitis.

\section{ACKNOWLEDGMENTS}

The authors thank Concetta Perilli (Dipartimento PRIME, Università di Foggia, Foggia, Italy) for her expert technical assistance and Claire Moore (Università di Foggia, Foggia, Italy) for English revision. This work was conducted using recombinant ovine IL-1 $\beta$ and IL-6 provided by Garry Barcham of the Centre for Animal Biotechnology, School of Veterinary Sciences, The University of Melbourne, Australia.

\section{REFERENCES}

Berning, L. M., M. J. Paape, R. H. Miller, and R. A. LaDane. 1987. N-acetyl-beta-D-glucosaminidase activities, milk somatic cell counts, and blood leukocyte and erythrocyte counts in cows after heat-induced stress or after intravenous administration of adrenocorticotropic hormone. Am. J. Vet. Res. 48:1157-1161.

Black, P. H. 2002. Stress and the inflammatory response: A review of neurogenic inflammation. Brain Behav. Immun. 16:622-653.

Borghetti, P., R. Saleri, E. Mocchegiani, A. Corradi, and P. Martelli. 2009. Infection, immunity and the neuroendocrine response. Vet. Immunol. Immunopathol. 130:141-162.

Bruckmaier, R. M., and J. W. Blum. 1998. Oxytocin release and milk removal in ruminants. J. Dairy Sci. 81:939-949.
Caroprese, M., M. Albenzio, G. Annicchiarico, and A. Sevi. 2006a. Changes occurring in immune responsiveness of single- and twinbearing Comisana ewes during the transition period. J. Dairy Sci. 89:562-568.

Caroprese, M., M. Albenzio, A. Muscio, and A. Sevi. 2006b. Relationship between welfare and udder health indicators in dairy ewes. Vet. Res. Commun. 30:83-94.

Caroprese, M., G. Annicchiarico, L. Schena, A. Muscio, R. Migliore, and A. Sevi. 2009. Influence of space allowance and housing conditions on the welfare, immune response and production performance of dairy ewes. J. Dairy Res. 76:66-73.

Day, M. J. 2000. Biology of Lymphocytes and Plasma Cells. Pages 240-246 in Schalm's Veterinary Hematology. B. F. Feldman, J. G. Zinkl, and N. C. Jain, ed. Lippincott \& Wilkins, Baltimore, MD.

Degabriele, R., and L. R. Fell. 2001. Changes in behaviour, cortisol and lymphocyte types during isolation and group confinement of sheep. Immunol. Cell Biol. 79:583-589.

Deiss, V., D. Temple, S. Ligout, C. Racine, J. Bouix, C. Terlouw, and A. Boissy. 2009. Can emotional reactivity predict stress responses at slaughter in sheep? Appl. Anim. Behav. Sci. 119:193-202.

Dhabhar, F. S. 2009. Enhancing versus suppressive effects of stress on immune function: Implications for immunoprotection and immunopathology. Neuroimmunomodulation 16:300-317.

Dhabhar, F. S., A. H. Miller, B. S. McEwes, and R. L. Spencer. 1996. Stress-induced changes in leukocyte distribution: Role of adrenal steroid hormones. J. Immunol. 157:1638-1644.

Dinarello, C. A. 1996. Biological basis for interleukin-1 in disease. J. Am. Soc. Hematol. 87:2095-2147.

Fell, L. R., D. A. Shutt, and C. J. Bentley. 1985. Development of a salivary cortisol method for detecting changes in plasma "free" cortisol arising from acute stress in sheep. Aust. Vet. J. 62:403406.

Fisher, A. D., M. A. Crowe, D. J. Prendiville, and W. J. Enright. 1997. Indoor space allowance: Effects on growth, behaviour, adrenal and immune responses of finishing beef heifers. Anim. Sci. 64:53-62.

Griffin, J. F. T. 1989. Stress and immunity: A unifying concept. Vet. Immunol. Immunopathol. 20:263-312.

Hemsworth, P. H., G. J. Coleman, J. L. Barnett, and S. Borg. 2000. Relationship between human-animal interaction and productivity of commercial dairy cows. J. Anim. Sci. 78:2821-2831.

Hopster, H., J. T. N. van der Werf, and H. J. Blokhuis. 1998. Stress enhanced reduction in peripheral blood lymphocyte numbers in dairy cows during endotoxin-induced mastitis. Vet. Immunol Immunopathol. 66:83-97.

Husband, A. J. 1995. The immune system and integrated homeostasis. Immunol. Cell Biol. 73:377-382.

IDF. 1990. Determination of milk fat, protein and lactose contentGuide for the operation of mid-infrared instruments. FIL-IDF Standard no. 141B. International Dairy Federation, Brussels, Belgium.

IDF. 1995. Enumeration of somatic cells. FIL-IDF Standard no. 148A International Dairy Federation, Brussels, Belgium.

Jones, R. B., and P. M. Hocking. 1999. Genetic selection for poultry behaviour: Big bad wolf or friend in need? Anim. Welf. 8:343359.

Kemeny, M. E. 2009. Psychobiological responses to social threat: Evolution of a psychological model in psychoneuroimmunology. Brain Behav. Immun. 23:1-9.

Kimura, K., J. P. Goff, M. E. Kehrli Jr., and J. A. Harp. 1999. Phenotype analysis of peripheral blood mononuclear cells in periparturient dairy cows. J. Dairy Sci. 82:315-319.

Koolhaas, J. M., S. M. Korte, S. F. De Boer, B. J. Van Der Vegt, C. G. Van Reenen, H. Hopster, I. C. De Jong, M. A. W. Ruie, and H. J. Blokhuis. 1999. Coping styles in animals: Current status in behavior and stress-physiology. Neurosci. Biobehav. Rev. 23:925935.

Kunz-Ebrecht, S. R., V. Mohamed-Ali, P. J. Feldman, C. Kirschbaum, and A. Steptoe. 2003. Cortisol responses to mild psychological stress associated with proinflammatory cytokines. Brain Behav. Immun. 17:373-383. 
Lloyd, J. B., H. S. Gill, and A. J. Husband. 1995. The effect of storage on immunophenotyping of sheep peripheral blood lymphocytes by flow cytometry. Vet. Immunol. Immunopathol. 47:135-142.

Maggio, M., J. M. Guralnik, D. L. Longo, and L. Ferrucci. 2006. Interleukin-6 in aging and chronic disease: A magnificent pathway. J. Gerontol. A Biol. Sci. Med. Sci. 61:575-584.

McEwen, B. S. 1998. Protective and damaging effects of stress medicine. Semin. Med Beth Israel Deaconess Medical Center 338:171-179.

McEwen, B. S., C. A. Biron, K. W. Brunson, K. Bulloch, W. H. Chambers, F. S. Dhabhar, R. H. Goldfarb, R. P. Kitson, A. H. Miller, R. L. Spencer, and J. M. Weiss. 1997. The role of adrenocorticoids as modulators of immune function in health and disease: Neural, endocrine and immune interactions. Brain Res. Brain Res. Rev. 23:79-133.

Mehrzad, J., D. Janssen, L. Duchateau, and C. Burvenich. 2008. Increase in Escherichia coli inoculum dose accelerates $\mathrm{CD} 8^{+} \mathrm{T}$-cell trafficking in the primiparous bovine mammary gland. J. Dairy Sci. 91:193-201.

Mehrzad, J., and X. Zhao. 2008. T lymphocyte proliferative capacity and $\mathrm{CD} 4^{+} / \mathrm{CD} 8^{+}$ratio in primiparous and pluriparous lactating cows. J. Dairy Res. 75:457-465.

Moberg, G. P. 2000. Biological response to stress. Pages 1-21 in The Biology of Animal Stress. G. P. Moberg and J. A. Mench, ed. CABI Publishing, Wallingford, UK.

Napolitano, F., G. Annicchiarico, M. Caroprese, G. De Rosa, L. Taibi, and A. Sevi. 2003. Lambs prevented from suckling their mothers displayed behavioral, immune, and endocrine disturbances. Physiol. Behav. 78:81-89.

Negrão, J. A., M. A. Porcionato, A. M. de Passillé, and J. Rushen. 2004 Cortisol in saliva and plasma of cattle after ACTH administration and milking. J. Dairy Sci. 87:1713-1718.

Park, Y. H., L. K. Fox, M. J. Hamilton, and W. C. Daws. 1992. Bovine mononuclear leukocyte subpopulations in peripheral blood and mammary gland secretions during lactation. J. Dairy Sci. 75:998-1006.

Rupp, R., D. Bergonier, S. Dion, M. C. Hygonenq, M. R. Aurel, C. Robert-Granié, and G. Foucras. 2009. Response to somatic cell count-based selection for mastitis resistance in a divergent selection experiment in sheep. J. Dairy Sci. 92:1203-1219.

Rushen, J. 2000. Some issues in the interpretation of behavioural responses to stress. Pages 23-42 in The Biology of Animal Stress. G. P. Moberg and J. A. Mench, ed. CABI Publishing, Wallingford, UK.

SAS Institute. 1999. SAS User's Guide: Statistics. Version 8.1 ed. SAS Inst. Inc., Cary, NC.

Sevi, A., G. Annicchiarico, M. Albenzio, L. Taibi, A. Muscio, and S. Dell'Aquila. 2001a. Effects of solar radiation and feeding time on behavior, immune response and production of lactating ewes under high ambient temperature. J. Dairy Sci. 84:629-640.

Sevi, A., M. Caroprese, G. Annicchiarico, M. Albenzio, L. Taibi, and A. Muscio. 2003. The effect of a gradual separation from the mother on later behavioral, immune and endocrine alterations in artificially reared lambs. Appl. Anim. Behav. Sci. 83:41-53.

Sevi, A., L. Taibi, M. Albenzio, A. Muscio, S. Dell'Aquila, and F. Napolitano. 2001b. Behavioral, adrenal, immune, and productive responses of lactating ewes to regrouping and relocation. J. Anim. Sci. 79:1457-1465.

Shapiro, S. S., and M. Wilk. 1965. An analysis of variance test for normality. Biometrika 52:591-601.

Shutt, D. A., and L. R. Fell. 1985. Comparison of total and free cortisol in bovine serum and milk or colostrum. J. Dairy Sci. 68:1832-1834.

Varner, M. A., and B. H. Johnson. 1983. Influence of adrenocorticotropin hormone upon milk production, milk constituents, and endocrine measures of dairy cows. J. Dairy Sci. 66:458-465.

Verkerk, G. A., A. M. Phipps, J. F. Carragher, L. R. Matthews, and K. Stelwagen. 1998. Characterization of milk cortisol concentrations as a measure of short-term stress responses in lactating dairy cows. Anim. Welf. 7:77-86.

Winter, P., M. Miny, K. Fuchs, and W. Baumgartner. 2006. The potential of measuring serum amyloid A in individual ewe milk and in farm bulk milk for monitoring udder health on sheep dairy farms. Res. Vet. Sci. 81:321-326. 